\title{
Euthanasia - some considerations on this matter
}

\section{Keywords: physician, euthanasia, fracturing, death Opinion}

To recognize the truth as truth and at the same time as a mistake; to live the contraries by not accepting them; feeling everything in every way and being nothing in the end, but the understanding of all ... "Fernando Pessoa, The Way of the Serpent.

Among what is conventionally called fracturing themes, euthanasia is perhaps the one that raises more questions and controversies. The question of executed death at the request of the patient by the physician or active euthanasia leads us to an issue that transcends us as professionals shaped for a culture of life.

With death, a specific and irreversible cultural universe undoubtedly ends for that particular human being who has deposited himself in our hands when ill, calling us for a journey with him as professionals, of quality of life or of preparation for death, in a physiological, natural, gentle way, without turmoil or suffering, without abbreviation or external intervention. This is the ideal perspective any health professional who would want regardless of whether or not considering as unquestionable the absolute sacredness of life. Living, aging and dying with dignity is in a society of democratic right the aim of all citizens; the dignity of all citizens is, moreover, consecrated in the P. R. C. (Portuguese Republic Constitution) but naturally the meaning of dignity is different for the various social actors.

That is why we cannot eliminate as if by magic all the doubts that may raise this question, before legislation more or less permissive in such a sensitive domain. To present doubts and controversies is also to contribute to a debate more and more urgent. The film by the Spanish director Alejandro Amenábar "Mar Adentro" tells the story of a quadriplegic Ramón Sampedro, who wished for years his death, requesting it to the judicial authorities of his country (Spain), as he could not do it independently. Putting a number of ethical questions related to the right to life, we ask ourselves about the recognition of the same right to death.

After all, what is to die worthily? What leads one to desire his own death? What should be the attitude of those surrounding you and who love you before such a request? To try to demonstrate him by acts and words that the body, although limited, is part of a biological unit inseparable from a thinking spirit, imaginative perhaps brilliant and powerful? That such a body is part of a whole indivisible and unique, also loved, appreciated, by the intelligence and imagination?

Or to give in and support his request and contribute for the success of his impetus at the margin of the law or not, being in respect to one of the principles of bioethics, which tells us that the doctrine of human dignity is under lied the principle of autonomy of the person, who is capable of deliberating his goals and acting in such a way that he will be all the more autonomous the more and better he is capable voluntarily, to self-determine in intellectual and affective terms. But where does respect for autonomy stand as a reality of the current medical practice? Autonomy that derives from the doctrine of respect for human dignity, which refuses to use man as a simple mean, meaning independence from external controls and action according to your own choice.

\author{
Volume 2 Issue I - 2018 \\ Leonor Duarte Almeida
Department of Ophthalmology, Medicine University of Lisbon,
Portugal
}

Correspondence: Leonor Duarte Almeida, Department of ophthalmology, Medicine University of Lisbon, Portugal,Tel 00351962918026,Email leonorduartealmeida@gmail.com

Received: January 15, 2017 | Published: January 25, 2018

How can society act? Not being by direct criminalization, knowing that some European countries benefit from legislation that allows the interruption of life at the request of the patient, provided he is lucid and autonomous in his own will?

How can society be able to value itself in a system where the individual is progressively invaded by the conception that the individual autonomy is the civilizational matrix that commands us, and the individual the center of the world? How to recreate a more humane civilization seen as Gabriel Marcel says in the full realization of the human being in the level of communion with others. ${ }^{1}$

In our civilizational European matrix, there is a demand for care that is portrayed in the interpellation of the face of the other, as expressed by Lévinas, claimed that the other is prior to the self. The human being becomes aware of himself in his relationship with others so that intersubjectivity constitutes a dimension of subjectivity itself. ${ }^{2}$

The answer may be to cultivate in practice this perspective of autonomy as a synonym for freedom, but within the integral respect for the autonomist idea apprehended as respect for the other, that is yes to attribute to the autonomous human being the capacity to give his own laws, but also to share them with his fellow human beings as Schramm says. ${ }^{3}$ It is in this sharing of decisions that involve others that there is the edification of the personality.

That is why when somebody wishes to die as a solution to his problem, for lack of self-esteem, for feeling stigmatized, suffering, as Scambler says, of internal stigma, which he feels even without existing stigmatization in practice (external), ${ }^{4}$ those who exclude themselves socially have to be confronted in a positive sense with this phenomenon, discussing intellectually in partnership with the other social characters, such as family, community, psychiatrist, friends. It will be a way of reinstating the question of the desire to die at a higher, dialogical level of understanding. Even suffering from external stigma, recognized by us that civil society is cruel, created for success, where the self predominates the nodes, it is important to discuss these phenomena in partnership with the patient, attributing dignity to whom is actually excluded. If a patient suffering from AIDS is discriminated in his workplace, be it the civil society, the doctor, the jurist, the family and the patient himself as a subject of rights, capable to decide for themselves, must mobilize energetically against exclusion.

The patient, quadriplegic or suffering from another "mental tetraplegia" can motivate the same internal and external stigmatization 
in a society where the beauty is the goal. But the AIDS patient mobilizes himself, moves, acts till death for life, with dignity, with higher goals, as in the excellent film Philadelphia, for the respect of human dignity. The bounded up by misfortune as "Sampedro", may have the same strength, the same prominence, if properly framed and supported. In the domains where the margins of a basic good such as human life bloom, we encounter "disintegrating conflicts of identity.

Regarding euthanasia and suicide can death be regarded as a form of care? In fact, a "help in dying" has been gaining strength through the advocates of (Hilfe zum Sterben), an "aid to die, with legislative consecration in the Netherlands, Belgium, or Luxembourg, or in the North-American State of Oregon. Reports are mobilized which can be expressed in the words of Sampedro - "Living is a right, not an obligation". In Portugal, the book Help Me to Die, by Laura Santos Ferreira tells us: death is a misfortune, but it is above all to end up a biographical life and not merely a biological one

\section{State of soul}

There will be some considerations needed in this discussion. First, the conceptual clarification is required in a time when the legitimate practices of cessation of care are wrongly understood as cases of euthanasia. We understand euthanasia as a "set of actions (active euthanasia) or omissions (passive euthanasia), practiced by someone other than the affected one, generally by health professional(s) aiming to practice death, at his request or not, being this conduct determined by the simple respect for autonomy or in the case of certain indications such as pain or suffering, of a moribund or incurable patient "; (although some authors consider as the true ones only the active euthanasia).

The suicide in criminal law terms is no longer criminalized. In the eighteenth century, criticisms against punishment are found in writers like Montesquieu, Voltaire, and Rousseau, though their defense persists in Kant in the Metaphysics of Customs: "Man cannot alienate his personality while the duties are at stake... as long as he lives; as to incitement or aids suicide continuing to integrate the Portuguese Penal Code.

Regarding euthanasia in our Criminal Code, Articles 134/1 (murder at the request of the victim) it expressly states that "Whoever kills another person" determined by a serious, instant and express request that he may have made is sentenced to prison up to 3 years "; and art. 133 (privileged homicide), drives us contrarily to the previous principle for involuntary euthanasia: "Whoever kills another person, who is dominated by an understandable violent emotion, compassion, despair, or motive of significant social or moral value, who significantly reduce his guilt, shall be prisoned from 1 to 5 years. "This precept does not cover cases in which the action is determined by eugenics or racism reasons.

Even the issues such as euthanasia and suicide are not beyond the control of the European Convention on Human Rights and the decision-making process of the European Court of Human Rights. Through a set of resolutions and recommendations, it is still influencing the conformation of the national legislations. In the argumentative confrontation, the search for solutions is drawn, placing the principles on the scale, rehearsing paths where constitutional readings and decision possibilities are crossed subject to a panoply of limits.

The mobilization of civil society with actions involving doctors, nurses, social workers, psychologists, bioethicists, associations, will be another component to integrate in this decision. Recently in Portugal the NCESL (National Council of Ethic for the Science of Life) which donates its non-legal binding opinion, promoted a large debate in several places all over the country where various aspects were discussed as the medical, legal and philosophical ones, and experiences were recollected from the countries where euthanasia is practiced and also from France and United Kingdom (which voted down the legislation two years ago for the practice of euthanasia but practice the so called assisted suicide). As the conclusion of debates' cycle an idea was emerged that any law that comes to life to normalize the practice of euthanasia approved by the politic parties in the Portuguese Republic Assembly cannot ever induce suffering. ${ }^{5}$ It is not the way that is difficult; it is the difficulty that is the way (Nietzsche)

\section{Acknowledgements}

None.

\section{Conflict of interest}

The author declares no conflict of interest.

\section{References}

1. Gabriel Marcel. Positions et approches concrètes du mystère ontologique. 1949. $91 \mathrm{p}$.

2. Emmanuel Lévinas. L'humanisme de l'autre homme. 1973. 128 p.

3. Mark-Oliver Baumgarten. The right to die? Rechtliche Probleme a Sterbenund Tod. Oxford, United Kingdom: Springer; 2002.

4. Morris D. Assisted suicide under the European convention on human rights: a critique. Eur Hum Rights Law Rev. 2003;(1):65-91.

5. http://www.cnecv.pt/ 